\section{Seashore Paspalum and Bermudagrass Response to Spray Applications of Postemergence Herbicides}

\author{
Alex J. Lindsey ${ }^{1,3}$, Joseph DeFrank ${ }^{1}$, and Zhiqiang Cheng ${ }^{2}$
}

AdDitional INDEX words. Cynodon dactylon, ethofumesate, golf course fairway, Paspalum vaginatum, mesotrione, metribuzin, safening, topramezone, weed control and suppression

Summary. The use of nonpotable water for irrigation on various sport venues has led to an increased use of seashore paspalum (Paspalum vaginatum) turf in Hawaii. An ongoing challenge many seashore paspalum turf managers struggle with is bermudagrass (Cynodon dactylon) infestations. Herbicide efficacy studies were conducted at the Hoakalei Country Club ['SeaDwarf' seashore paspalum (fairway cut)] and the Magoon Research Station ['SeaStar' seashore paspalum (grown in container)] on the island of Oahu in Hawaii. Spray applications of the herbicides mesotrione, topramezone, metribuzin, and ethofumesate were evaluated alone and in tank mixtures for bermudagrass suppression and seashore paspalum injury. At the Hoakalei Country Club, maximum bermudagrass injury with minimal seashore paspalum discoloration was obtained with tank mixes of mesotrione $(0.06 \mathrm{lb} / \mathrm{acre})+$ metribuzin $(0.19 \mathrm{lb} / \mathrm{acre})+$ ethofumesate $(1.00 \mathrm{lb} / \mathrm{acre})$ and topramezone $(0.02$ $\mathrm{lb} /$ acre $)+$ metribuzin $(0.19 \mathrm{lb} /$ acre $)+$ ethofumesate $(1.00 \mathrm{lb} / \mathrm{acre})$. Unacceptable seashore paspalum turf injury was obtained in all treatments that did not include metribuzin. At the Magoon Research Station, maximum selective bermudagrass suppression was achieved with tank mixes of topramezone $(0.01 \mathrm{lb} / \mathrm{acre})+$ ethofumesate $(1.00 \mathrm{lb} /$ acre $)$ and topramezone $(0.01 \mathrm{lb} /$ acre $)+$ metribuzin $(0.09$ $\mathrm{lb} /$ acre $)+$ ethofumesate $(1.00 \mathrm{lb} / \mathrm{acre})$. The addition of metribuzin and/or ethofumesate to the tank mix safened (reduced turf discoloration) seashore paspalum to topramezone or mesotrione foliar bleaching. Tank mixes of mesotrione, topramezone, metribuzin, and ethofumesate have the potential for bermudagrass suppression and control of other grassy weeds in seashore paspalum turf.

$\mathrm{I}$ $n$ recent years, some golf courses in Hawaii have replaced or are replacing bermudagrass with seashore paspalum on greens or as their primary fairway turfgrass. Emphasis on potable water conservation and increased use of recycled water on turfgrass are major contributors to increased soil salinity (Duncan and Carrow, 1998). This

Received for publication 2 Jan. 2019. Accepted for publication 20 Feb. 2019.

Published online 2 April 2019

This research was supported in part by a grant awarded to Z. Cheng and J. DeFrank through College of Tropical Agriculture and Human Resources' (CTAHR) competitive Supplemental Hatch Funding Program. We also thank Hoakalei Country Club for contributing turfgrass sites used in the research reported here, as well as Hawaiian Turfgrass and corporate sponsors for providing some experimental materials used in this research.

${ }^{1}$ Department of Tropical Plant and Soil Sciences, University of Hawaii at Manoa, 3190 Maile Way, St. John Plant Science Lab 102, Honolulu, HI 96822

${ }^{2}$ Department of Plant and Environmental Protection Sciences, University of Hawaii at Manoa, 3050 Maile Way, Gilmore Hall 609, Honolulu, HI 96822

${ }^{3}$ Corresponding author. E-mail: alexlind@hawaii.edu.

This is an open access article distributed under the CC BY-NC-ND license (https://creativecommons.org/ licenses/by-nc-nd/4.0/).

https://doi.org/10.21273/HORTTECH04267-19 increase in soil salinity has contributed to high tolerance to saline soils and nonpotable irrigation water (Lee et al., 2004). Bermudagrass irrigated with saline nonpotable water results in unacceptable turf quality (Wiecko, 2003).

As more seashore paspalum golf courses are established, bermudagrass contamination is a common unsolved problem among Hawaii's turfgrass managers. The only selective herbicide labeled for bermudagrass suppression in seashore paspalum is ethofumesate (Bayer CropScience, 2017a). Selective suppression of bermudagrass is attributed to higher foliar and root absorption the use of seashore paspalum due to its of ethofumesate relative to seashore paspalum (McCullough et al., 2016). Bermudagrass suppression in seashore paspalum turf was achieved by sequential applications of ethofumesate plus flurprimidol. However, seashore paspalum injury was considered unacceptable for practical use (Johnson and Duncan, 2000). Ethofumesate, fluazifop, and clethodim alone or in combinations have been ineffective at bermudagrass suppression, and damage to the seashore paspalum was considered unacceptable (McCullough, 2017).

Bermudagrass control on golf courses has relied on spot treatments of glyphosate (Johnson, 1988). However, selective bermudagrass suppression has been achieved in st. augustinegrass (Stenotaphrum secundatum) with sequential applications of ethofumesate plus atrazine (McCarty, 1996). Atrazine is not labeled for use on turfgrass in Hawaii and causes unacceptable injury to seashore paspalum (Purdue University, 2018; Yu et al., 2015). Bermudagrass suppression in zoysiagrass (Zoysia sp.) was achieved with multiple applications of fenoxaprop + triclopyr or fluazifop + triclopyr (McElroy and Breeden, 2006). Fenoxaprop, fluazifop, and triclopyr cause unacceptable injury to seashore paspalum (McCullough, 2017). In this study, herbicides were evaluated for suppression of bermudagrass and seashore paspalum injury and foliar discoloration.

\section{Materials and methods}

Preliminary study. An experiment was conducted on a 'SeaDwarf' seashore paspalum driving range, maintained at a fairway cut $(0.5$ inch mowing height), at Hoakalei Country Club (Ewa Beach, HI) in Aug. 2017. Seashore paspalum turfgrass at this site was established on imported soil overlaying a coral outcrop soil (Coarse-loamy, mixed, semiactive, frigid Argic Endoaquods). Herbicide

\begin{tabular}{llll}
\hline $\begin{array}{l}\text { Units } \\
\text { To convert U.S. to SI, } \\
\text { multiply by }\end{array}$ & U.S. unit & SI unit & $\begin{array}{l}\text { To convert SI to U.S., } \\
\text { multiply by }\end{array}$ \\
\hline 29.5735 & $\mathrm{fl} \mathrm{oz}$ & $\mathrm{mL}$ & 0.0338 \\
0.3048 & $\mathrm{ft}$ & $\mathrm{m}$ & 3.2808 \\
3.7854 & $\mathrm{gal}$ & $\mathrm{L}$ & 0.2642 \\
9.3540 & $\mathrm{gal} / \mathrm{acre}$ & $\mathrm{L} \cdot \mathrm{ha}^{-1}$ & 0.1069 \\
2.54 & $\mathrm{inch}(\mathrm{es})$ & $\mathrm{cm}$ & 0.3937 \\
1.1209 & $\mathrm{lb} / \mathrm{acre}$ & $\mathrm{kg} \cdot \mathrm{ha}^{-1}$ & 0.8922 \\
28.3495 & $\mathrm{oz}$ & $\mathrm{g}$ & 0.0353 \\
6.8948 & $\mathrm{psi}$ & $\mathrm{kPa}$ & 0.1450
\end{tabular}


treatments (Table 1) were applied using a single-nozzle boom fitted with an air induction nozzle tip (TeeJet AI 9508 E; Spraying Systems Co., Wheaton, IL). Each treatment plot was $3 \mathrm{ft}$ wide by $15 \mathrm{ft}$ long, with a $1-\mathrm{ft}$ nontreated area between experimental units. Herbicide treatments were prepared in $3-\mathrm{L}$ plastic bottles and applied with a $\mathrm{CO}_{2}$-powered backpack sprayer calibrated to apply 44 $\mathrm{gal} / \mathrm{acre}$ at $30 \mathrm{psi}$. The spray system was rinsed with water between treatments to prevent cross contamination. Herbicides were applied on 1 Aug. 2017.

The experimental design was a randomized complete block with four replications. Visual ratings of green color $(0=$ brown $/$ white to $100=$ maximum attainable green color) were recorded at $\approx 7$-d intervals for seashore paspalum. For this experiment, maximum turfgrass green color was the highest level of green color observed outside of the test area and unaffected by experimental spray applications. The minimum commercially acceptable green color rating was set at $80 \%$ for seashore paspalum turf. Analysis of variance (ANOVA) for green color ratings was conducted with Statistix (version 10.0; Analytical Software, Tallahassee, FL). Herbicide treatment means were separated using Tukey's mean testing.

REPEATED FAIRWAY EXPERIMENT. Experiments were conducted on a 'SeaDwarf' seashore paspalum driving range, maintained at a fairway cut
(0.5 inch mowing height), infested with bermudagrass at Hoakalei Country Club (Ewa Beach, HI) in Dec. 2016 and June 2017. Seashore paspalum turfgrass at this site was established on imported soil overlaying a coral outcrop soil (Coarse-loamy, mixed, semiactive, frigid Argic Endoaquods). Herbicide treatments (Table 2) were applied using a singlenozzle boom fitted with an air induction nozzle tip (TeeJet AI 9508 E). Each treatment plot was $3 \mathrm{ft}$ wide by $15 \mathrm{ft}$ long, with a $\mathrm{l}$-ft nontreated area between experimental units. The herbicides were prepared in $3-\mathrm{L}$ plastic bottles and applied with a $\mathrm{CO}_{2-}$ powered backpack sprayer calibrated to apply $44 \mathrm{gal} / \mathrm{acre}$ at $30 \mathrm{psi}$. The spray system was rinsed with water between treatments to prevent cross contamination. Expt. I application dates were 21 Dec. 2016 and 31 Jan. 2017 (4l d apart). Expt. 2 application dates were 20 June 2017 and 1 Aug. 2017 (42 d apart). Experimental starting dates were selected to represent the start of winter and summer seasons in Hawaii, Expts. 1 and 2, respectively.

The experimental design was a split-plot with four replications. Experimental run was the main factor with herbicide treatment as the subfactor. Visual ratings of green color $(0=$ brown $/$ white to $100=$ maximum attainable green color) were recorded for seashore paspalum and bermudagrass. For this experiment, maximum turfgrass green color was the highest

Table 1. Response of 'SeaDwarf' seashore paspalum fairways to postemergence herbicides applied at the Hoakalei Country Club (Ewa Beach, HI) on 1 Aug. 2017.

\begin{tabular}{lccc}
\hline & \multicolumn{3}{c}{ Visual green color rating (\%) $^{\mathrm{y}}$} \\
\cline { 2 - 4 } Herbicide treatment $^{\mathrm{z}}$ & 7 DAS01 $^{\mathrm{x}}$ & 14 DAS01 & 22 DAS01 \\
\hline Mesotrione & $72.0 \mathrm{~b}^{\mathrm{w}}$ & $88.8 \mathrm{bc}$ & $94.5 \mathrm{a}$ \\
Mesotrione + metribuzin & $84.3 \mathrm{ab}$ & $94.3 \mathrm{ab}$ & $95.5 \mathrm{a}$ \\
Mesotrione + ethofumesate & $81.8 \mathrm{ab}$ & $85.5 \mathrm{~cd}$ & $91.0 \mathrm{ab}$ \\
Mesotrione + metribuzin + ethofumesate & $83.5 \mathrm{ab}$ & $96.5 \mathrm{a}$ & $95.8 \mathrm{a}$ \\
Topramezone & $41.0 \mathrm{c}$ & $22.5 \mathrm{e}$ & $93.5 \mathrm{a}$ \\
Topramezone + metribuzin & $80.8 \mathrm{ab}$ & $95.3 \mathrm{a}$ & $95.5 \mathrm{a}$ \\
Topramezone + ethofumesate & $77.5 \mathrm{ab}$ & $80.0 \mathrm{~d}$ & $87.0 \mathrm{~b}$ \\
Topramezone + metribuzin + ethofumesate & $78.5 \mathrm{ab}$ & $93.8 \mathrm{ab}$ & $94.0 \mathrm{a}$ \\
Nontreated & $96.3 \mathrm{a}$ & $96.3 \mathrm{a}$ & $94.8 \mathrm{a}$ \\
$F$ value & 9.96 & 311.61 & 7.65 \\
$P$ value & $<0.0001$ & $<0.0001$ & $<0.0001$ \\
\hline
\end{tabular}

${ }^{\mathrm{z}}$ Herbicides were applied at the following rates (lb/acre): 0.06 mesotrione, 0.19 metribuzin, 1.00 ethofumesate, and 0.02 topramezone. All treatments received methylated seed oil $(2.0 \% \mathrm{v} / \mathrm{v})$, added for enhanced foliar penetration; $1 \mathrm{lb} /$ acre $=1.1209 \mathrm{~kg} \cdot \mathrm{ha}^{-1}$.

VVisual green color rating $(0=$ brown $/$ white, $100=$ maximum attainable green color $)$.

${ }^{\mathrm{x}} \mathrm{DASOl}=$ days after initial spray application

"Means within rating sequence column followed by the same letters are not significantly different as determined by Tukey's honestly significant difference at $P<0.05$. level of green color observed outside of the test area and unaffected by experimental spray applications. The minimum commercially acceptable green color rating was set at $80 \%$ for seashore paspalum turf. Analysis of variance for green color ratings was conducted with Statistix (version 10.0). Means were separated using Tukey's mean testing.

REPEATED CONTAINER EXPERIMENT. Experiments were conducted on 'SeaStar' seashore paspalum and common bermudagrass at Magoon Research facility (Honolulu, HI) in Sept. and Oct. 2017. 'SeaStar' seashore paspalum was obtained from Hawaiian Turfgrass (Mililani, HI). Common bermudagrass, established on a rock land soil (Fine-loamy, mixed, active, frigid Typic Eutrudepts), was collected from a known stand at a Honolulu residence (lat. $21.351055^{\circ} \mathrm{N}$, long. $157.918806^{\circ} \mathrm{W}$ ). Two sprigs of seashore paspalum and bermudagrass were planted in separate 0.43 -gal containers (TP49 Short One Mini-Treepots; Stuewe \& Sons, Tangent, OR) filled with $53 \mathrm{oz}$ of growing medium. Growing medium was prepared by mixing 8 gal of general purpose growing medium (Pro-Mix BX Mycorrhizae; Premier Tech Horticulture, Rivière-du-Loup, Canada), 4 gal of silica sand, and $10.5 \mathrm{oz}$ of slow-release fertilizer (Osmocote 14N-4.2P11.6K; Everris NA, Dublin, $\mathrm{OH}$ ). Each pot received $1.76 \mathrm{fl} \mathrm{oz}$ of water three times per day from overhead irrigation. Macro and minor turf nutrients (Gaviota Foliar 60 19N8.3P-15.8K; BEI Hawaii, Honolulu, $\mathrm{HI}$ ) were supplied in a volume of $3.4 \mathrm{fl} \mathrm{oz}$ per pot, formulated to provide $40 \mathrm{lb} /$ acre $\mathrm{N}$, every $14 \mathrm{~d}$. Turf was clipped at $14-\mathrm{d}$ intervals with a handheld cordless lithium garden shear/shrubber combo (2in-1; Black+Decker, Towson, MD) and was grown until the surface of the growth medium container was completely covered. Expt. I was planted on 18 May 2017, and Expt. 2 was planted on 13 July 2017.

Herbicide treatments (Table 3 ) were applied using a single-nozzle boom fitted with an air induction nozzle tip (TeeJet AI 9508 E). Herbicides were prepared in 3 -L plastic bottles and applied with a $\mathrm{CO}_{2}$-powered backpack sprayer calibrated to apply $44 \mathrm{gal} / \mathrm{acre}$ at $30 \mathrm{psi}$. The spray 
Table 2. Response of 'SeaDwarf' seashore paspalum (SP) and bermudagrass (BG) in fairways to postemergence herbicides applied at the Hoakalei Country Club (Ewa Beach, HI) in 2016 and 2017.

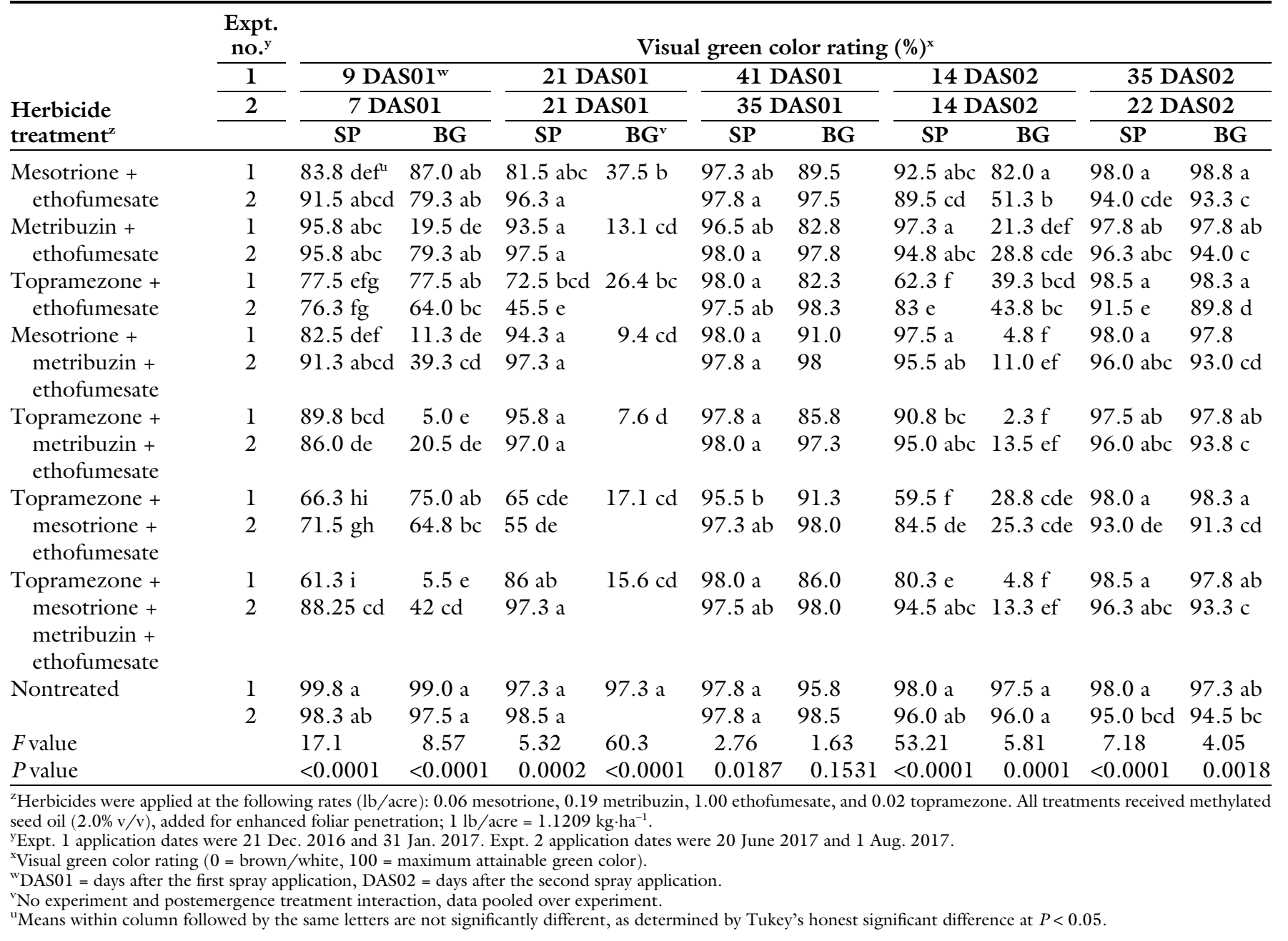

system was rinsed with water between treatments to prevent cross contamination. Spray treatments were applied in a shrouded polyvinyl chloride box to prevent drift and maintain consistent boom height above turf containers. Expt. 1 application date was 29 Sept. 2017 (134 $\mathrm{d}$ of growth before herbicide application). Expt. 2 application date was 13 Oct. 2017 (92 d of growth before herbicide application). One hour after herbicide treatments were applied, the automatic overhead irrigation turned on in Expt. 1. In Expt. 2, the irrigation was turned off for $1 \mathrm{~d}$ after herbicide application.

The experimental design was a split-plot two-way factorial with four replications. Experimental run was the main factor with species and herbicide treatment as subfactors. Visual ratings of green color $(0=$ brown/white to $100=$ maximum attainable green color) were recorded at 7-d intervals for seashore paspalum and bermudagrass. The minimum commercially acceptable green color rating was set at $80 \%$ for seashore paspalum turf. Dry weights of clippings were recorded at $\approx 21-\mathrm{d}$ intervals for seashore paspalum and bermudagrass. Initial clippings (Expt. 1 was on 28 Sept. 2017, Expt. 2 was on 12 Oct. 2017) were collected before herbicide application and used as a covariant within the analysis of variance. Turf was clipped using a handheld cordless lithium garden shear/shrubber combo (2-in-1). The difference in foliar dry weight production between treated and nontreated experimental units was based on turf clippings and expressed with the equation $\{[$ (treatment dry weight nontreated dry weight)/nontreated dry weight $] \times 100\}$. Negative values represent a reduction in growth relative to nontreated and positive values represent an increase in growth. The analysis of variance for green color ratings and expression of foliar dry weight production was conducted with Statistix (version 10.0). Means were separated using Tukey's mean testing.

\section{Results}

Preliminary study. The ANOVA indicated a significant herbicide treatment effect $(P<0.05)$ on seashore paspalum green color ratings (Table 1). At $7 \mathrm{~d}$ after the initial spray application (7 DAS01), topramezone resulted in the lowest seashore paspalum green color ratings compared with all other treatments. The addition of metribuzin and/or ethofumesate to topramezone resulted in significantly higher seashore paspalum green color compared with topramezone alone. Topramezone caused significantly more green color loss than mesotrione. Although not significantly different, the addition of metribuzin 
Table 3. Response of 'SeaStar' seashore paspalum (SP) and common bermudagrass (BG) turf grown in containers to postemergence herbicides applied at the Magoon Research Station (Honolulu, HI) in 2017.

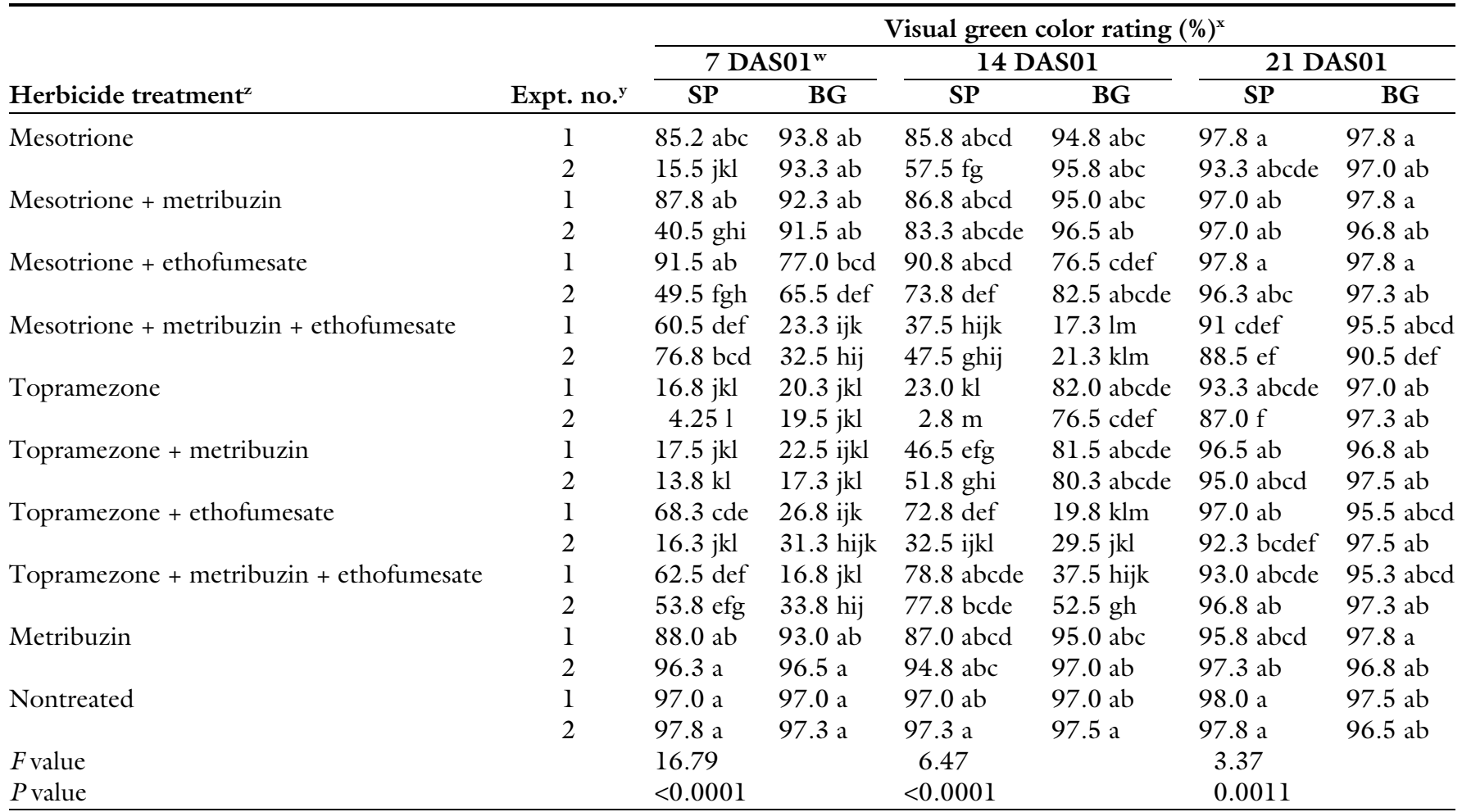

${ }^{\mathrm{z}}$ Herbicides were applied at the following rates ( $\mathrm{lb} /$ acre): 0.06 mesotrione, 0.09 metribuzin, 1.00 ethofumesate, and 0.01 topramezone. All treatments received methylated seed oil $(1.0 \% \mathrm{v} / \mathrm{v})$, added for enhanced foliar penetration; $1 \mathrm{lb} / \mathrm{acre}=1.1209 \mathrm{~kg} \cdot \mathrm{ha}^{-1}$.

'Expt. 1 application date was 29 Sept. 2017. Expt. 2 application date was 13 Oct. 2017.

${ }^{x}$ Visual green color rating $(0=$ brown/white, $100=$ maximum attainable green color $)$.

"DASOl = days after initial spray application. All treatments and species recovered to prespray condition by 28 DASOl (data not reported). Means in rows and columns within the rating sequence column followed by the same letters are not significantly different as determined by Tukey's honestly significant difference at $P<0.05$.

and/or ethofumesate to mesotrione resulted in higher seashore paspalum green color. At 14 DAS01, a further reduction in seashore paspalum green color was recorded for topramezone alone, which was the only treatment below the limit of commercial acceptability (i.e., less than $80 \%$ ). However, the addition of metribuzin and/or ethofumesate to topramezone did result in green color that was of commercial acceptability. At 21 DAS01, green color returned to prespray conditions for all treatments except topramezone + ethofumesate.

REPEATED FAIRWAY EXPERIMENT. The ANOVA indicated a significant interaction between experimental run and herbicide treatment effect $(P<0.05)$ on seashore paspalum green color ratings (Table 2 ). In ratings recorded $21 \mathrm{~d}$ after initial spray application (21 DAS01), only topramezone + ethofumesate and topramezone + mesotrione + ethofumesate showed significant seashore paspalum green color loss relative to the nontreated. Green color in all the other treatments was above commercially acceptable standards (i.e., greater than
$80 \%)$. The addition of metribuzin to topramezone + ethofumesate and topramezone + mesotrione + ethofumesate resulted in significantly higher seashore paspalum green color ratings for both experiments. All treatments recovered to prespray conditions by the next rating dates (Expt. 1 was 4l DAS01 and Expt. 2 was 35 DAS01). Seashore paspalum green color ratings recorded on $14 \mathrm{~d}$ after the second spray application (14 DAS02) were similar to those recorded 21 DAS01. Topramezone + ethofumesate and topramezone + mesotrione + ethofumesate produced the lowest seashore paspalum green color ratings, however, the addition of metribuzin to tank mix did result in higher green color ratings. Seashore paspalum green color ratings for topramezone + ethofumesate and topramezone + mesotrione + ethofumesate were significantly lower in the winter season (Expt. 1) than the summer season (Expt. 2). All treatments recovered to an acceptable green color level by the next rating date (Expt. 1 was 35 DAS02 and Expt. 2 was 22 DAS02).
The ANOVA indicated a significant interaction between experimental run and herbicide treatment effect $(P<0.05)$ on bermudagrass color ratings. There was no interaction between experimental run and herbicide treatment effect on bermudagrass green color ratings recorded 21 DAS0l, data poled over experimental run (Table 2). In ratings recorded 21 DAS01, all treatments were significantly lower than the nontreated. Metribuzin + ethofumesate, mesotrione + metribuzin + ethofumesate, topramezone + metribuzin + ethofumesate, topramezone + mesotrione + ethofumesate, and topramezone + mesotrione + metribuzin + ethofumesate had the lowest bermudagrass green color ratings. The addition of metribuzin to mesotrione + ethofumesate and topramezone + ethofumesate significantly lowered bermudagrass green color ratings. All treatments recovered to greater than $80 \%$ green color by the next rating dates (Expt. 1 was 41 DAS01 and Expt. 2 was 35 DAS01). On ratings recorded 14 DAS02, bermudagrass green color ratings were lowest for mesotrione + metribuzin + ethofumesate, 
topramezone + metribuzin + ethofumesate, and topramezone + mesotrione + metribuzin + ethofumesate. Although not significant, green color in Expt. 1 was generally lower than Expt. 2. The addition of metribuzin to mesotrione + ethofumesate, topramezone + ethofumesate, and topramezone + mesotrione + ethofumesate (Expt. 1) resulted in significantly lower bermudagrass green color ratings. Bermudagrass green color recovered to greater than $80 \%$ at 35 DAS02 and 22 DAS02, Expts. 1 and 2 respectively.

REPEATED CON T A I N E R EXPERIMENT. The ANOVA indicated a significant interaction between experimental run, species, and herbicide treatment effect $(P<0.05)$ on green color ratings $14 \mathrm{~d}$ after spray applications (14 DAS01) (Table 3). Green color loss was visually greater for seashore paspalum than bermudagrass in response to applications of mesotrione and topramezone (Fig. 1). In Expt. 2, mesotrione, topramezone, and topramezone + ethofumesate resulted in significantly lower seashore paspalum green color compared with Expt. 1. Expt. 2 had a 1-d delay in irrigation following herbicide application, and Expt. I received irrigation $\mathrm{l} \mathrm{h}$ after herbicide treatments were applied. The addition of metribuzin and/or ethofumesate to mesotrione or topramezone increased seashore paspalum green color. Recovery of bermudagrass green color after topramezone application was delayed when ethofumesate was added. Seashore paspalum green color was higher than bermudagrass for mesotrione + metribuzin + ethofumesate and topramezone + metribuzin + ethofumesate. Metribuzin alone appeared to be more injurious to seashore paspalum foliar tissue than bermudagrass (Fig. 1), not a significant result as reflected in green color ratings (Table 3 ). Small needle shaped foliage in seashore paspalum was severely injured by metribuzin, similar injury not observed in bermudagrass. Both grass species recovered to above commercially acceptable levels (i.e., greater than $80 \%$ ) by the next rating date (21 DASOl).

The ANOVA indicated a significant interaction between species and herbicide treatment effect $(P<0.05)$ for the difference between foliage dry weight production between treated and nontreated experimental units recorded $21 \mathrm{~d}$ after the initial spray

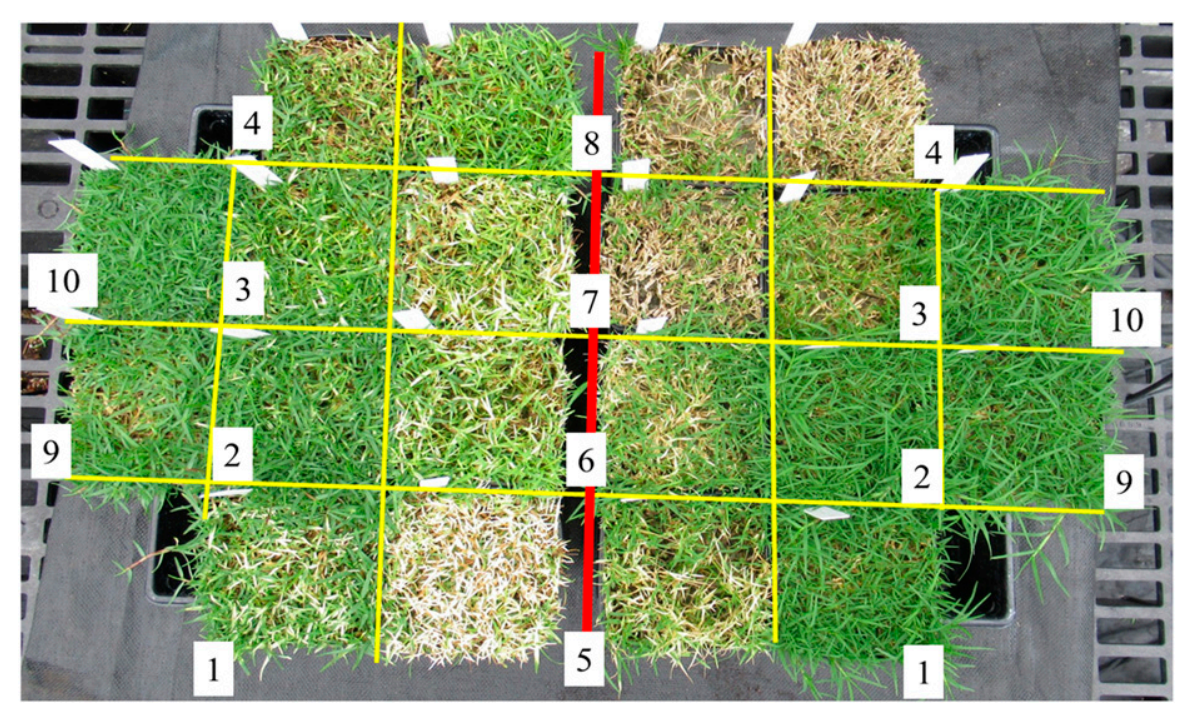

Fig. 1. Representative response of 'SeaStar' seashore paspalum and common bermudagrass $14 \mathrm{~d}$ after herbicide treatments, Expt. 2, at the Magoon Research Station (Honolulu, HI). Seashore paspalum is on the left of the red line and bermudagrass is on the right. Herbicide treatment: Trt $1=$ mesotrione, Trt $2=$ mesotrione + metribuzin, Trt $3=$ mesotrione + ethofumesate, Trt $4=$ mesotrione + metribuzin + ethofumesate, Trt $5=$ topramezone, Trt $6=$ topramezone + metribuzin, Trt $7=$ topramezone + ethofumesate, Trt $8=$ topramezone + metribuzin + ethofumesate, Trt $9=$ metribuzin, and Trt $10=$ nontreated.

Herbicides were applied at the following rates (lb/acre): 0.06 mesotrione, 0.09 metribuzin, 1.00 ethofumesate, and 0.01 topramezone. All treatments received methylated seed oil $(1.0 \% \mathrm{v} / \mathrm{v})$, added for enhanced foliar penetration; $1 \mathrm{lb} /$ acre = $1.1209 \mathrm{~kg} \cdot \mathrm{ha}^{-1}$.

application (21 DAS01) (Fig. 2). All herbicide treatments caused a reduction in seashore paspalum growth with the highest level of growth reduction caused by mesotrione + metribuzin + ethofumesate. Mesotrione + metribuzin and metribuzin alone resulted in the least amount of bermudagrass growth reduction. The highest level of bermudagrass growth reduction was recorded with mesotrione + metribuzin + ethofumesate and topramezone + ethofumesate. No treatment provided a selective response where bermudagrass growth suppression significantly exceeded seashore paspalum suppression. Only treatments containing ethofumesate resulted in bermudagrass suppression that was numerically higher than seashore paspalum.

\section{Discussion}

Preliminary study. Seashore paspalum green color loss caused by mesotrione and topramezone was reduced with the addition of metribuzin. All tank mixes that included metribuzin recovered to pre-spray conditions by 14 DAS01, $7 \mathrm{~d}$ sooner than treatments with topramezone or mesotrione alone. Bermudagrass safening (reduced turf discoloration) to topramezone bleaching has been reported with addition of chelated iron to the tank mix (Boyd et al., 2016). Normally, the addition of a photosystem II inhibitor (metribuzin) to a tank mixture with an 4hydroxyphenylpyruvate dioxygenase (HPPD) inhibitor (topramezone and mesotrione) herbicide increases phototoxicity due complementary mode of actions or synergism (Armel et al., 2005; BASF Corporation, 2017; Bayer CropScience, 2017b; Syngenta Crop Protection, 2017). However, the results in this study indicate that metribuzin added to the tank mix minimized green color loss of seashore paspalum in response to mesotrione and topramezone. Similar results occurred with ethofumesate, but to a lesser degree than metribuzin. The reduction in seashore paspalum green color loss was attributed to growth inhibition imposed by metribuzin and/or ethofumesate by reducing apical foliar growth where HPPD bleaching is most prominent (BASF Corporation, 2017; Bayer CropScience, 2017a; Gunsolus and Curran, 2002; McCullough et al., 2016; Syngenta 


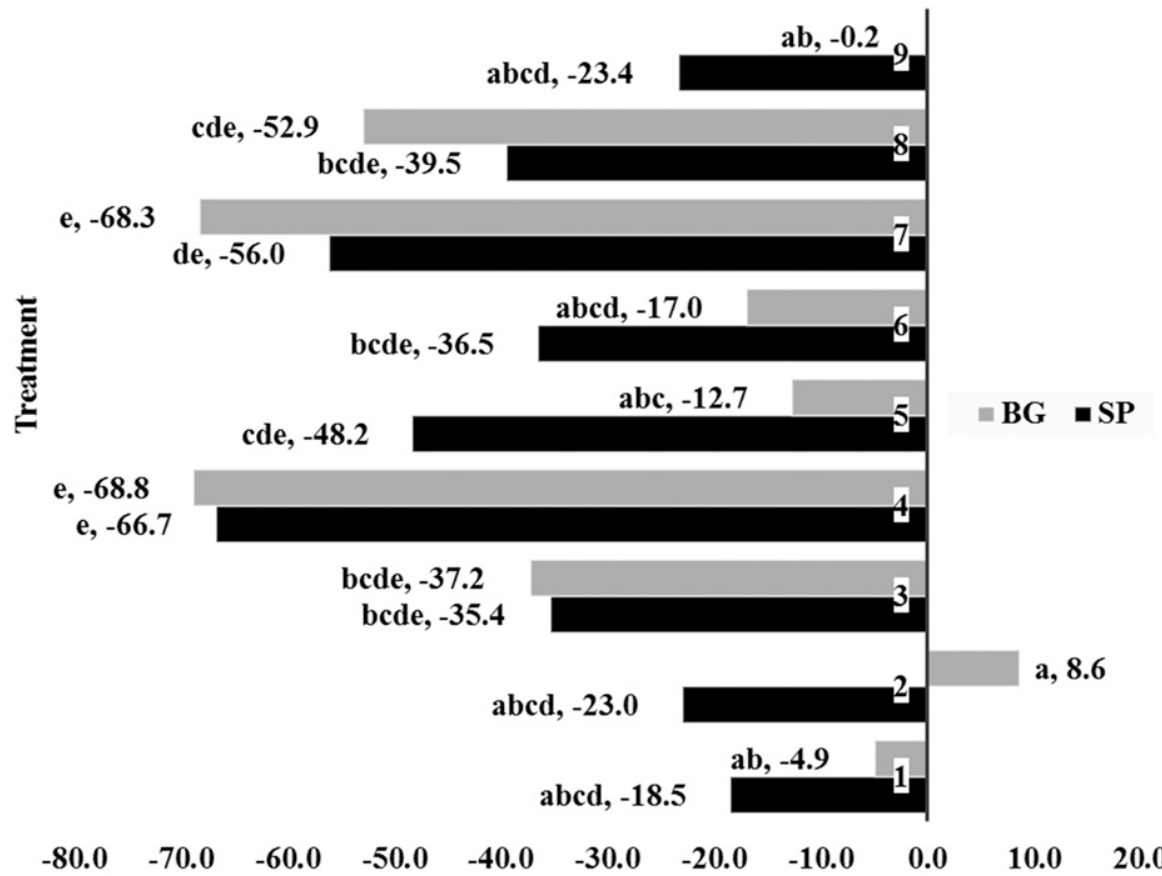

Change relative to nontreated (\%)

Fig. 2. 'SeaStar' seashore paspalum (SP) and common bermudagrass (BG) difference between foliage dry weight production $21 \mathrm{~d}$ after herbicide application at the Magoon Research Station (Honolulu, HI). The percent change relative to nontreated was derived using the equation $\{[$ (treatment dry weight - nontreated dry weight) $/$ nontreated dry weight $] \times 100\}$. Negative values represent a reduction in growth relative to nontreated. Herbicide treatment (Trt): Trt $1=$ mesotrione, Trt 2 = mesotrione + metribuzin, Trt 3 = mesotrione + ethofumesate, Trt $4=$ mesotrione + metribuzin + ethofumesate, Trt $5=$ topramezone, Trt $6=$ topramezone + metribuzin, Trt $7=$ topramezone + ethofumesate, Trt $8=$ topramezone + metribuzin + ethofumesate, Trt $9=$ metribuzin, and Trt $10=$ nontreated. Herbicides were applied at the following rates (lb/acre): 0.06 mesotrione, 0.09 metribuzin, 1.00 ethofumesate, and 0.01 topramezone $(1 \mathrm{lb} /$ acre $\left.=1.1209 \mathrm{~kg} \cdot \mathrm{ha}^{-1}\right)$. All treatments received methylated seed oil $(1.0 \% \mathrm{v} / \mathrm{v})$, added for enhanced foliar penetration. The analysis of variance indicated a significant interaction between species and treatment $(P=0.02, F=2.39)$. Means followed by the same letters are not significantly different as determined by Tukey's honestly significant difference at $P<0.05$.

Crop Protection, 2017). Metribuzin and/or ethofumesate added as a tank mix to mesotrione or topramezone can mitigate green color loss in seashore paspalum.

REPEATED FAIRWAY EXPERIMENT. The addition of metribuzin to tank mixes containing topramezone reduced green color loss in seashore paspalum, a response similar to the preliminary study. The addition of metribuzin to the ethofumesate tank mixes increased bermudagrass injury that was higher in the winter compared with summer applications. Winter applications could impose greater injury due to slower bermudagrass growth and lower metabolic processes that can detoxify herbicides (Foy, 2006). Winter irrigation needs were reduced due to cooler daytime conditions and less evaporative stress than the summer season. Metribuzin, mesotrione, and topramezone are highly water-soluble and have moderate to very high leaching potentials (Lewis et al., 2016). Herbicides with high water solubility are more likely to leach with excessive irrigation or heavy rainfall (Jhala, 2017). With less irrigation, herbicide residency in the root zone is increased resulting in more bermudagrass absorption, which may have resulted in more intense and persistent green color loss. Conversely, the decreased discoloration in the summer is attributed to higher levels of irrigation that can flush herbicides from the root zone and faster growing turf that is more tolerant to herbicides or that can more rapidly metabolize absorbed toxins (McCullough, n.d.).

Mesotrione + metribuzin + ethofumesate and topramezone + metribuzin + ethofumesate were identified as the most effective treatments for selective bermudagrass suppression with minimal loss of green color on seashore paspalum. However, long-term bermudagrass suppression was not achieved in this study. Long-term selective suppression of bermudagrass may require sequential applications, a use pattern consistent with the current ethofumesate product label (Bayer CropScience, 2017a). Bermudagrass recovered as quickly as $22 \mathrm{~d}$ after the last herbicide application, so sequential applications would have to be made before $21 \mathrm{~d}$ after the last application. Additional applications made outside the $21 \mathrm{~d}$ window may result in less bermudagrass suppression.

REPEATE D CONTAINER EXPERIMENT. Mesotrione and topramezone applied alone caused more green color loss and growth suppression in seashore paspalum than bermudagrass. The reduced seashore paspalum turf green color loss associated with metribuzin and/or ethofumesate as a tank mix component in field studies was less obvious in the container study. Decreased green color loss attributed to metribuzin could be due to cultivar differences ('Sea Dwarf' seashore paspalum in the field vs. 'SeaStar' seashore paspalum in containers) or due to a dramatically different root zone environment between field and container grown plants. Plants grown in containers tend to be more sensitive to herbicides because they generally have smaller root systems than field-grown established plants (Wilen and Elmore, 2014). Daily watering of the containerized plants could also have an impact on the chemical residency in the grass root zone. Containerized roots may have a shorter duration of chemical exposure than field grown plants thus reducing root absorption and reduced green color loss. The unintended restart of overhead irrigation (Expt. 1) greatly reduced the green color loss in treatments that contained topramezone, a highly watersoluble chemical. However, control/ suppression was unaffected by the unintended restart of irrigation as 
indicated by the clippings data. The high water solubility of topramezone may also account for the reduced green color loss in containerized plants compared with field grown plants. Visual injury in the form of green color loss is a more serious issue for turf managers that prefer to use herbicides that minimize the negative visual impact to the desired turf species. The addition of metribuzin to mesotrione or topramezone did not have an impact on bermudagrass green color or growth. However, treatments with ethofumesate resulted in significantly lower green color ratings and growth, a result consistent with enhanced ethofumesate green color loss in bermudagrass in field plots at the Hoakalei Country Club. It is also consistent with the ethofumesate label, which describes selective bermudagrass suppression (Bayer CropScience, 2017a).

Mesotrione + metribuzin + ethofumesate, topramezone + ethofumesate, and topramezone + metribuzin + ethofumesate provided the greatest interspecies differences in green color ratings that were higher for seashore paspalum. Mesotrione + metribuzin + ethofumesate recorded the highest level of growth reduction for both the seashore paspalum and bermudagrass even though seashore paspalum green color was much higher than bermudagrass. Topramezone + ethofumesate and topramezone + metribuzin + ethofumesate caused a greater reduction relative to the nontreated dry weight for bermudagrass compared with seashore paspalum. Thus, topramezone + ethofumesate and topramezone + metribuzin + ethofumesate provided the highest level of selective bermudagrass suppression in this study.

In summary, topramezone and mesotrione turf discoloration in seashore paspalum was reduced with the addition of metribuzin and/or ethofumesate to the tank mix. The greatest loss in bermudagrass green color was imposed by the three-way tank mixes of mesotrione + metribuzin + ethofumesate and topramezone + metribuzin + ethofumesate and the two-way mix of topramezone + ethofumesate. These treatments cause much less green color loss in seashore Paspalum, even though the growth suppression is among the highest for both species. We conclude that the highest level of selective bermudagrass suppression with the lowest level of seashore paspalum green color loss was obtained with the three-way tank mix of topramezone + metribuzin + ethofumesate.

\section{Literature cited}

Armel, G.R., G.J. Hall, H.P. Wilson, and N. Cullen. 2005. Mesotrione plus atrazine mixtures for control of canada thistle (Cirsium arvense). Weed Sci. 53:202211.

BASF Corporation. 2017. Pylex ${ }^{\mathrm{TM}}$ herbicide supplemental label. BASF Corp., Research Triangle Park, NC.

Bayer CropScience. 2017a. Prograss ${ }^{\circledR}$ herbicide product label. Bayer CropScience LP, Bayer Environmental Science, Montvale, NJ.

Bayer CropScience. 2017b. Sencor ${ }^{\circledR}$ DF $75 \%$ dry flowable herbicide product label. Bayer CropScience LP, Environmental Science Division. Research Triangle Park, NC.

Boyd, A., J.S. McElroy, W. Head, and P.E. McCullough. 2016. Attempted safening of topramezone on bermudagrass. Amer. Soc. Agron., Crop Sci. Soc. Amer., Soil Sci. Soc. Amer., Intl. Annu. Mtg. p. 99754 (abstr.).

Duncan, R.R. and R.N. Carrow. 1998. Salt affected turfgrass sites: Assessment and management. Ann Arbor Press, Chelsea, MI.

Foy, J.H. 2006. Selecting the right grass. USGA Green Sect. Rec. 44:1-8.

Gunsolus, J. and W. Curran. 2002. Herbicide mode of action and injury symptoms. Univ. Minnesota, North Central Reg. Ext. Publ. 377.

Jhala, A. 2017. Effect of excessive rainfall on efficacy of residual herbicides applied in corn and soybean. 8 Feb. 2019. <https://cropwatch.unl.edu/2017/ effect-excessive-rainfall-efficacy-residualherbicides-applied-corn-and-soybean> .

Johnson, B.J. 1988. Glyphosate and SC0224 for bermudagrass (Cynodon spp.) cultivar control. Weed Technol. 2:20-23.

Johnson, B.J. and R.R. Duncan. 2000. Timing and frequency of ethofumesate and flurprimidol treatments of bermudagrass (Cynodon spp.) suppression in sea- shore paspalum (Paspalum vaginatum). Weed Technol. 14:675-685.

Lee, G., R.R. Duncan, and R.N. Carrow. 2004. Salinity tolerance of seashore paspalum ecotypes: Shoot growth responses and criteria. HortScience 39:1138-1142.

Lewis, K.A., J. Tzilivakis, D. Warner, and A. Green. 2016. An international database for pesticide risk assessments and management. Human ecological risk assessment. Intl. J. 22:1050-1064.

McCarty, L.B. 1996. Selective control of common bermudagrass in st. augustinegrass. Crop Sci. 36:694-698.

McCullough, P. n.d. Are temperatures too high to safely apply herbicides in turf? 8 Feb. 2019. <http://caes2.caes.uga. edu / com modities / turfgras / georgiaturf/LandscapeAlert/Herbicide\% 20Temps\%20(7-11).html>.

McCullough, P. 2017. Herbicides \& weed control. 10 Mar. 2017. <http:// www.seashorepaspalum.uga.edu/ paspalum-management/herbicidesweed-control $/>$.

McCullough, P.E., J. Yu, and C.R. Johnston. 2016. Physiological basis for bermudagrass control with ethofumesate in seashore paspalum and st. augustinegrass. Crop Sci. 56:1306-1313.

McElroy, J.S. and G.K. Breeden. 2006. Triclopyr safens the use of fluazifop and fenoxaprop on zoysiagrass while maintaining bermudagrass suppression. Appl. Turfgrass Sci. 3(1), doi:10.1094/ATS2006-0502-01-RS.

Purdue University. 2018. National Pesticide Information Retrieval System. 6 Mar. 2018. <http://nspirs.ceris.purdue.edu/ htbin/prlist.com>.

Syngenta Crop Protection. 2017. Tenacity ${ }^{\circledR}$ herbicide product label. Syngenta Crop Protection, LLC, Greensboro, NC.

Wiecko, G. 2003. Ocean water as a substitute for postemergence herbicides in tropical turf. Weed Technol. 17:788791.

Wilen, C. and C. Elmore. 2014. Integrated weed management, p. 225-236. In: J. Newman (ed.). Container nursery production and business management manual. Univ. California, Div. Agr. Natural Resources Publ. 3540.

$\mathrm{Yu}$, J., P.E. McCullough, and M.A. Czarnota. 2015. Seashore paspalum tolerance to amicarbazone at various seasonal application timings. Weed Technol. 29:42-47. 